\title{
TRAFIKMODELLERS BETYDNING FOR GRØN MOBILITET
}

En diskussion af datagrundlaget for Københavns trafikmodel

\section{RASMUS TYGE HAARLØV}

Denne artikel undersøger et af de centrale styringsredskaber, hvormed kampen om Københavns byrum bliver udkæmpet. Trafikmodeller har afgørende indflydelse på, hvordan byens rum bliver præsenteret for embedsfolk og beslutningstagere, idet nogle elementer af trafikken fremhæves på bekostning af andre. I denne artikel undersøger jeg forskellen på den nuværende og kommende trafikmodel for København med henblik på at forstå, hvordan disse teknologier understøtter byens mål om grønnere mobilitet og $\mathrm{CO}_{2}$-neutralitet i 2025 .

\section{Stigende trængsel i en tættere by}

I Københavns Kommune er der henholdsvis 1,1 cykler og 0,2 biler i gennemsnit pr. indbygger. 62 procent af københavnerne cykler til og fra arbejde eller uddannelse, mens blot 9 procent tager bilen. Dermed er cyklen det suverænt mest populære transportmiddel (Københavns Kommune 2019a). For en by, der bryster sig af at være verdens bedste cykelby, er det dog bemærkelsesværdigt, at asfalterede veje til biler inklusive parkeringspladser samlet set fylder 66 procent af byens gaderum, mens kun 7 procent af gaderummet er dedikeret til cykelstier (Astrup 2017). Så selv om København ligger i toppen af ranglister over cykelbyer, er København dog først og fremmest en bilcentreret by. Trængslen blandt bilister i København er imidlertid så høj, at en bilist i gennemsnit kører $8 \mathrm{~km} / \mathrm{t}$. - eller halvt så hurtigt som en cyklist - i myldretiden på trafikale hovedårer som H.C. Andersens Boulevard. Samtidig skønnes det, at trængslen på vejene kommer til at stige med 150 procent for bilister frem mod 2030 (Mcghie 2018). Udbygningen af cykelstier i hovedstaden har været en stor succes de seneste årtier, men der er behov for mere plads, da nye elektriske køretøjer såsom elløbehjul, elskateboards og ikke mindst elcykler og speed pedelecs med en topfart på op til $45 \mathrm{~km} / \mathrm{t}$. indtager de ofte smalle cykelstier. 
København har som mål at være $\mathrm{CO}_{2}$-neutral i 2025, og transportsektoren er i den forbindelse en stor udfordring, som halter langt efter de ambitiøse målsætninger. 34 procent af byens $\mathrm{CO}_{2}$-udledning stammer fra transportsektoren (Københavns Kommune 2019b:8). Med udgangspunkt i en undersøgelse af den nuværende og kommende trafikmodel for København og omegn er formålet med denne artikel at demonstrere, hvorledes trafikmodellering påvirker og influerer ,transportsynet" blandt embedsfolk og beslutningstagere. Årsagen til, at kommunen har valgt at bestille en ny trafikmodel,er blandt andet, at trafikplanlæggere og embedsfolk, herunder programleder for cyklisme Marie Kåstrup, er utilfredse med den nuværende models bias i forhold til bilisme på bekostning af cyklisme og fodgængere. Samtidig er den nuværende transportmodel ikke brugervenlig, hvilket betyder, at modellen er utilgængelig for kommunens medarbejdere. Københavns Kommunes medarbejdere er således nødsaget til at hyre eksterne rådgivere, når de skal have foretaget nye trafikberegninger. Det og meget andet skal der laves om på i den nye model, som skal være klar til brug i sommeren 2020.

\section{Interviews med ledende kommunale embedsfolk}

Som led i et større forskningsprojekt om grøn omstilling i transportsektoren, hvor vi er interesserede $i$ at undersøge, hvordan grøn omstilling finder sted på den korte, jordnære bane i modsætning til langsigtede politiske $\mathrm{CO}_{2}$-mål i 2050, interviewede jeg i efteråret 2018 en række ledende embedsfolk, herunder Marie Kåstrup, programleder for cyklisme i Københavns Kommune, Sidsel Hjuler, leder af Sekretariatet for Supercykelstier, Sidsel Kjems, chefkonsulent i Københavns Kommune, Goran Vuk, tidligere Vejdirektoratet, nu selvstændig, samt Klaus Bondam, tidligere teknik- og miljøborgmester, nu formand for Cyklistforbundet. Formålet med interviewene var at undersøge, hvilke udfordringer kommunale medarbejdere står over for i deres daglige arbejde i forbindelse med grøn omstilling af byens transport. Metodisk set er Laura Naders idéer om at studere „opad“ (1972) relevante i denne sammenhæng, da mine informanter og forskningsdeltagere bestrider ledende embedsposter og dermed er med til at udøve magt på højt niveau. Ifølge Nader har magtfulde embedsfolk i store bureaukratiske institutioner eller økonomiske eliter i store virksomheder som regel mere indflydelse på samfundets udvikling end for eksempel fattige bønder i det globale syd. Antropologer bør underforstået rette fokus mod eliter og magtcentre i stedet for marginaliserede grupper (Nader 1972:289). Det kendetegnende ved indsamling af empiri, når man studerer ,opad“, er, at det som udgangspunkt ikke er muligt at gennemføre deltagerobservation, medmindre man som for eksempel antropolog Karen Ho (2009) ønsker at blive en del af den gruppe, der studeres. I mit tilfælde 
havde jeg ikke mulighed for at blive embedsmand og trafikplanlægger. Derfor bygger empirien i denne artikel på interviews og dokumenter. Marie Kåstrup og Sidsel Hjuler understregede begge, at modellering af cyklisme i den nuværende transportmodel er problematisk. Den nuværende transportmodel, der går under navnet Ørestads Trafik Model (herefter OTM), modellerer cyklisme på et lavere niveau end bilisme og kollektiv trafik, hvilket Kåstrup understregede i løbet af interviewet, og det forhindrer en hurtigere udbygning af cykelstier. Anledningen til at fokusere på trafikmodellering blev forstærket af, at Københavns Kommune i 2017 bestilte en ny trafikmodel, som er under udvikling i skrivende stund. Mens Marie Kåstrup, Sidsel Hjuler og Klaus Bondam har stor viden om udfordringerne for grøn mobilitet, er de ikke specialister i transportmodellering. Derfor bygger empirien i denne artikel primært på interviewene med Goran Vuk, som har været en af drivkræfterne bag den nuværende transportmodel, og som i skrivende stund arbejder som ekstern konsulent på den nye model, samt interviewet med Sidsel Kjems, der er projektleder på den nye, kommende trafikmodel. I det næste afsnit introducerer jeg den teoretiske rammesætning, som ligger til grund for analysen af de to transportmodeller.

\section{Teknologimediering og kommunal datasynlighed}

For bedre at kunne forstå, hvordan en trafikmodel former „synet“ og transportoverblikket hos embedsfolk og politikere, inddrager jeg antropolog James Scotts idéer om, hvordan en stat ser, samt postfænomenolog Peter-Paul Verbeeks idéer om, hvordan teknologier kan siges at åbne verden.

Antropologer har i årtier interesseret sig for policy, og hvordan policy producerer magt, kroppe, subjekter eller særlige diskurser (se blandt andet Hansen 1997; Shore \&Wright 1997; Apthorpe 1997). Ligeledes beslægtet med dette forskningsprojekt er David Graebers genfortolkning af antropologiske klassikere om udveksling og værdi samt Bill Maurers teoretiske diskussion af penges performative karakter, idet transportmodellering er en form for værdisætning, som indgår i økonomiske samfundsanalyser (Graeber 2001; Maurer 2006). For nærværende projekt er postfænomenologiske indsigter, der bygger videre på teknologifilosof Don Ihdes idéer om teknologiforståelse, relevante at inddrage. Postfænomenologer er inspireret af fænomenologiens grundlæggere Edmund Husserl, Martin Heidegger og Maurice Merleau-Ponty. Disse tænkere var optaget af, hvordan menneskets intentionalitet er rettet mod bestemte ting (Husserl), hvorledes mennesket gennem teknologi åbner verden (Heidegger), samt hvordan teknologier bliver kropsliggjorte i særlige brugssituationer (Merleau-Ponty). Postfænomenologer bygger videre på disse interesser for menneskets bevidsthed, krop og væren-i-ver- 
den, dog med den forskel, at menneske-teknologi-hybrid-relationer står i fokus. Postfænomenologiske forskere har for eksempel undersøgt, hvordan medicinstuderende tænkes som programmerbare objekter (Kaposy 2015), oplevelsen af ,selftracking"-teknologier vedrørende kropslig monitorering (Van Den Eede 2015) samt udviklingen af mobilitet og hastighedsopfattelse i det 20. århundrede (Riis 2015). En grundpræmis i postfænomenologien er, at mennesker som udgangspunkt er teknologiske væsener, der dels former teknologi, dels bliver formet af den teknologi, som er omkring os. Teknologi påvirker vores hverdag og oplevelser, den spiller en afgørende rolle for vores liv og velvære, og teknologi bruges ligeledes i forbindelse med moralske beslutninger (Verbeek 2011:4). En grundidé i postfænomenologien er derfor, at teknologier bør undersøges for etiske implikationer. Postfænomenologiens opgave er dermed at undersøge, hvordan teknologi medierer verden, for herved bliver det muligt at vurdere moralske aspekter af teknologi (op.cit.15-16, 56). Hvor oplysningstiden medførte en overførsel af moral fra Gud til menneske, er det nu relevant at spørge, i hvilket omfang moral skal uddelegeres til teknologi (Verbeek 2011). Selv om teknologi ikke kan siges at have bevidsthed i menneskelig forstand, argumenterer Verbeek for, at intentionalitet kan være distribueret mellem teknologi og menneske i forskellig grad. Mange af de relationer, vi har med vores omgivelser, sker således ved hjælp af teknologi; verden medieres gennem briller, temperaturen medieres gennem en termostat, og telefonen medierer samtalen. I tråd med denne logik medierer transportmodeller trafikfænomener for byplanlæggere. Verbeek taler således om, at teknologisk intentionalitet koblet med menneskelig intentionalitet skaber en form for hybridintentionalitet. Når teknologi medierer menneskets syn på verden, forstærkes nogle elementer af virkeligheden, mens andre fænomener bliver reduceret (op.cit.8-9). På samme måde som et manuskript dikterer slagets gang i en film, har teknologier også en form for indbygget „script“ (Akrich \& Latour i Verbeek 2011:10). En plastikkop foreskriver for eksempel at blive smidt ud efter brug, mens et vejbump foreskriver, at man sænker hastigheden, inden dette passeres (op.cit.10). I forlængelse heraf analyserer jeg, hvordan transportmodeller kalder på bestemte trafikale ændringer, afhængigt af om det for eksempel er bilisme, kollektiv trafik, fodgængere eller cyklisme, som bliver fremhævet.

Mens postfænomenologer altså interesserer sig for, hvordan teknologier repræsenterer og medierer verden, er James Scotts ærinde at kaste lys på sammenhængen mellem synlighed og statslige interventioner. I Seeing Like a State (1995) beskriver Scott således, hvorledes „legibility“ - forstået som det, en embedsmand eller politiker kan se eller læse fra sit kontor - er afgørende for, at stater kan udøve samfundsmæssige interventioner og manipulere en given befolkning eller natur. En forudsætning for at opkræve skatter, indkalde mænd til værnepligt, 
fange kriminelle, vaccinere en befolkning eller administrere en skov er, at staten kan repræsentere skoven eller befolkningen gennem simplificerede abstraktioner i form af kort eller tal (Scott 1998:22). Jo mere viden en stat opnår om en skov eller en befolkning, jo mere har staten også mulighed for at manipulere denne (ibid.). Dette er en af de centrale pointer i Scotts klassiker. Statslig indsamling af data om borgere, som Scott kalder en form for ,intern kolonisering“, stopper aldrig og sker kontinuerligt. Jævnfør Scott er det relevante spørgsmål for nærværende undersøgelse, hvordan transportmodellerne gør visse transportfænomener mere synlige end andre, samt hvordan synligheden ændrer sig fra den nuværende transportmodel til den kommende model. Hvilke transportfænomener kaster de to modeller særligt lys på? Før jeg dykker ned i forskellene på modellerne, introducerer jeg indledningsvis forholdet mellem trafikmodeller og samfundsøkonomiske analyser i en dansk kontekst, da det er en forudsætning for at forstå, hvad der er på spil i forbindelse med trafikmodellering.

\section{Trafikmodellering og samfundsøkonomiske analyser}

En trafikmodel er et softwareprogram, der har til formål at modellere transportadfærd blandt en befolkningsgruppe i et begrænset område på baggrund af en række forskellige inputs. De første trafikmodeller blev til i begyndelsen af 1950'ernes USA, hvor nogle få softwareudviklere begyndte at interessere sig for at simulere trafikkryds og små distancer gennem programmering. Herefter fortsatte udviklingen, og hvert årti frem mod i dag har medført store fremskridt inden for disciplinen, som kulminerede i udviklingen af regionale simulationsbaserede modeller, som i dag bruges af praktikere overalt i verden (Liebermann 2015:17). Mange byer anvender trafikmodeller, og et fællestræk for disse er, at de primært er bygget op omkring bilisme og veje, delvist kollektiv trafik og i begrænset omfang cyklister og fodgængere (Kjems, Paag \& Hansen 2018: 19). Trafikmodellering producerer grundlæggende en simplificeret repræsentation af verden, idet nogle transportfænomener fremhæves ud fra et særligt perspektiv på bekostning af andre elementer, der dermed ikke vurderes relevante. Simplificering er ikke som sådan problematisk, men det bliver det, når vigtige variabler systematisk udelades i trafikmodeller (Beimborn, Kennedy \& Schafer 1996 i Andersen 2013:7). Set fra et grønt mobilitetsperspektiv er fodgængere og cyklister eksempelvis vigtige variabler, fordi disse transportformer medfører lave $\mathrm{CO}_{2}$-udledninger. Regionale og urbane trafikmodeller i Danmark har historisk set primært haft til formål at producere viden om trafikale forhold vedrørende bilisme. Jensen et al. (2017) beskriver, hvordan cyklisme tilbage i 1930'erne var den dominerende transportform, men siden bilen blev udbredt i efterkrigstidstiden, 
har cyklisme været usynligt som planlægningsobjekt, fordi man betragtede bilen som fremtidens transportform. I 1990'erne ændrede dette sig, da socioøkonomiske sundhedsgevinster ved cyklisme blev udregnet. Disse udregninger gjorde cyklisme synligt som epistemisk fænomen, og derved blev cyklisme modtagelig for kvantitative målsætninger (Jensen, Cashmore \& Elle 2017:466, 473). Ifølge Andersen har trafikmodeller desuden forsømt at tage højde for, at udvidelser af vejnettet til bilisme på sigt medfører mere trængsel på vejene som følge af en stigning i udbredelsen og brugen af biler.

Realtidsovervågning af trafikken er endnu ikke teknisk muligt og bliver det formentlig heller ikke inden for en overskuelig fremtid. Derfor er matematisk modellering i dag stadigvæk den mest oplagte måde at anskueliggøre en bys trafikfænomener på. Selv om den nuværende og kommende model er særdeles komplekse softwarestørrelser, omtaler jeg herefter modellerne som henholdsvis den snævre, nuværende model og den bredere, kommende model. I den forbindelse bør det dog pointeres, at den nuværende trafikmodel er state-of-the-art inden for trafikmodellering i Danmark.

I transportsektoren er der desuden tradition for, at potentielle infrastrukturscenarier bliver analyseret i samfundsøkonomiske cost-benefit-analyser. Formålet med udarbejdelsen af samfundsøkonomiske analyser er at finde frem til de fordele og ulemper, der er ved et bestemt infrastrukturprojekt. Analysen omfatter som udgangspunkt de fordele og ulemper, der tilfalder indbyggerne i Danmark, mens virkninger, der påvirker andre landes indbyggere, ikke medtages (Vejdirektoratet 2018). Samfundsøkonomiske analyser omfatter ud over udgifter og indtægter i forbindelse med en infrastrukturinvestering også afledte effekter såsom $\mathrm{CO}_{2}$-udledning, støjgener, uheld og luftforurening (Finansministeriet 2018a). På transportområdet bruges en regnearksmodel for samfundsøkonomisk analyse, der går under navnet TERESA (Transport- og Boligministeriets Regnearksmodel for Samfundsøkonomisk Analyse). Version 1.0 af TERESA blev oprindeligt udviklet gennem et samarbejde mellem ingeniørvirksomheden COWI, Transportog Energiministeriet og Danmarks Tekniske Universitet i 2006 (DTU Center for Transport Analytics 2019). Modellen er naturligvis præget af den tid, som den er et produkt af, og i sin oprindelige version $1.0 \mathrm{blev}$ modellen konstrueret med det formål at kunne beregne bilisme og kollektiv trafik.

Mens TERESA som nævnt historisk set har modelleret cyklisme begrænset, blev modellen i 2018 videreudviklet, således at den nu modellerer cyklisme på samme niveau som bilisme og kollektiv trafik. Modellen bliver opdateret cirka hvert andet år i henhold til udviklingen i befolkning, brændstofpriser og BNP, men hyppigere opdateringer kan forekomme, hvis en ny kalkulationsrente fra Finansministeriet for eksempel presser sig på (ibid.). I regnearket TERESA kan 
man se, at $\mathrm{CO}_{2}$-beregninger først beskrives nederst $\mathrm{i}$ introduktionen under kategorien ,eksterne omkostninger". Kategoriseringen og placeringen i regnearket indikerer med andre ord, at $\mathrm{CO}_{2}$-udregninger ikke er centrale i TERESA. De samfundsøkonomiske analyser på transportområdet bygger på trafikmodellering, og ofte er det ganske få elementer såsom rejsetid eller anlægsomkostninger, der afgør udfaldet af det samlede resultat (Krawack 2015:5). Ifølge Finansministeriet skal samfundsøkonomiske analyser betragtes som et „beslutningsstøtteværktøj“, idet disse kan bidrage med at indsnævre og rangere potentielle løsningsforslag i henhold til deres samfundsøkonomiske afkast (op.cit.117). Men som Dreze og Stern påpeger, kan der være flere måder ud over cost-benefit-analyser, hvorpå man evaluerer og beslutter sig for et givent infrastrukturprojekt. Disse inkluderer anvendelsen af magt, intern forhandling eller flertalsafstemninger (Dreze \& Stern 1987:909). I nærværende forskningsprojekt har jeg ikke haft adgang til situationer, hvor resultater fra TERESA kombineret med særlige magtrelationer mellem embedsmænd og lokalpolitikere resulterer i valget af nye anlægsprojekter, men i det følgende afsnit ses der nærmere på, hvordan beregningen af nøgleparameteret rejsetid har stor betydning for, hvilken type infrastrukturinvestering der vælges.

\title{
Trængsel som dominerende modelleringsfokus
}

Sidsel Kjems, der tidligere har forsket i adfærdsøkonomi og nu er projektleder for Københavns Kommunes nye trafikmodel, beskriver i det følgende, hvordan trafikmodellering generelt set bruges i Københavns Kommune:

\begin{abstract}
Modellering af transportadfærd bliver typisk brugt til at kunne forudse de trafikale konsekvenser af et scenarie. En transportmodel sammenligner to scenarier: et status quo og et scenarie, som indeholder den ændring, man ønsker at kende de trafikale konsekvenser af. En ændring kan være ny infrastruktur som en motorvej eller en cykelbro. Det kan også være en stigning i befolkningen eller mange andre forhold. Embedsmanden kan vælge at få vist resultatet af beregningen, altså de trafikale konsekvenser af en ændring i mange forskellige nøgletal, afhængigt af formålet med beregningen. Et resultat kan for eksempel være rejsetiden for bilister fra A til B, tal for den samlede trafikmængde opsplittet på forskellige trafikmodes (cykler, gående, kollektiv og bil), samt hvilke rejseruter disse trafikanter vælger. Dette er blot eksempler på output fra trafikmodelberegninger, som indeholder mange variabler og dermed mange mulige resultattyper.
\end{abstract}

Set i lyset af Scott (1998) gør transportmodeller med andre ord særlige trafikfænomener, herunder rejsetid, synlige for en embedsmand eller beslutningstager gennem datarepræsentationer. For at illustrere et typisk anvendelsesscenarie for den 
nuværende Ørestad Trafik Model (OTM) er her et uddrag fra interviewet med Goran Vuk. Han er tidligere trafikforsker på DTU og embedsmand i Vejdirektoratet. Da jeg interviewede Vuk i efteråret 2018, var han ansat i Vejdirektoratet, i dag arbejder han som selvstændig konsulent på den nye, udvidede trafikmodel. I løbet af sin karriere som forsker på DTU har han været med til at udvikle den nuværende trafikmodel, som har været i brug siden midten af 1990'erne. I det følgende citat beskriver Vuk, hvem de typiske brugere af OTM er, samt hvad der ofte er på spil for brugere af modellen.

Hvad du får, det er belastninger på veje, hvor mange biler der kommer over hele hovedstadsregionen, som OTM dækker. Med hensyn til kollektiv trafik får du at vide, for eksempel mellem Valby og København, hvor mange der kører med S-tog og med metrocityringen. [...] Men det, det handler om [for brugeren], det er, at du sidder i et firma, en organisation, you name it, Københavns Kommune, Movia, Metro, og siger, jeg har en idé om, hvordan vi kan tjene flere penge.

I ovenstående beskriver Vuk, hvordan modellen bruges til at beregne belastningen på veje samt mængden af S-togspassagerer mellem stationer. Dernæst refererer Vuk til sammenhængen mellem, hvor mange passagerer metroen eller Movia kan transportere, og hvor stor en indtjening virksomhederne kan have. Set fra et kommunalt perspektiv er der ligeledes et ønske om at forbedre rejsetiden for indbyggerne i København, i og med at passagerer dermed kan transportere sig hurtigere til og fra arbejde eller indkøbsmuligheder, hvilket resulterer i flere skatter i kommunekassen. Set fra et postfænomenologisk perspektiv (Verbeek 2011:8-9) fremhæver transportmodellen altså rejsetid i henhold til bilisme og kollektiv trafik på bekostning af andre transportmodi såsom fodgængere og cyklister eller eksternaliteter såsom luftforurening eller $\mathrm{CO}_{2}$-udledning. Firmaer som Metroselskabet og Movia samt offentlige institutioner som Vejdirektoratet og Københavns Kommune kan med andre ord anvende modellen til at teste de økonomiske effekter af potentielle fremtidige investeringer. I lyset af Latour og Akrichs idé om teknologiers iboende „script“ kan man sige, at trafikmodellen kalder på, at trængslen på vejene bør optimeres (Akrich \& Latour i Verbeek 2011: 10) med henblik på at øge en økonomisk bundlinje. Modellens smalle fokus på rejsetid er dog ikke uproblematisk. Det forklarer Kjems, som er projektleder for den kommende, bredere transportmodel, i følgende citat:

Men cyklisme og gang i det her [den nuværende, snævre OTM] lider stadig af den måde, man laver beregninger på. Så vi kan beregne gennemsnitlige rejsetider, men hvis man så laver Østre Ringvej, bliver rejsetiden måske forbedret for bilister. Problemet med det her det er, at ovre i de samfundsøkonomiske modeller, der tæller rejsetid rigtig meget, så hvis bilister sidder i kø, tæller det rigtig negativt. Så hvis man kan lave et infrastrukturprojekt, der kan forbedre rejsetiden, bliver 
det rigtig, rigtig godt [i den samfundsøkonomiske model]. Det, der er ulempen, det er, at cyklister ikke har det, at vi bliver forsinkede på samme måde, og det tæller altså træls - om jeg så må sige - $\mathrm{i}$ en samfundsøkonomisk model. Og jeg ved sgu ikke helt, hvordan man skal løse det.

I ovenstående forklarer Sidsel Kjems, hvordan trafikmodellens beregninger af rejsetid bruges i regnearksmodellen TERESA for samfundsøkonomisk analyse. Den tid, som en bil kan vinde ved en vejudvidelse, er måske 15 minutter i et givent scenarie fra A til B, forklarer Kjems, mens samme forbedring for en cyklist kun drejer sig om mindre end et minut. Fremhævelsen af trængsel, som den nuværende transportmodels ,script“ (Akrich \& Latour i Verbeek 2011:10) producerer i den samfundsøkonomiske analyse, kalder med andre ord på, at der gøres noget ved trængsel for bilister. Fremhævelsen af trængselsfænomenet i trafikmodellen kommer altså i højere grad bilister til gode på bekostning af cyklister, for hvem en vejudvidelse i mindre grad påvirker rejsetiden. Derimod vil en vejudvidelse på smalle cykelstier forbedre trygheden på cykelstien, fordi der bliver bedre plads, men dette kan ikke aflæses i trafikmodellen. I øjeblikket er over halvdelen af alle bilture i Danmark under $10 \mathrm{~km}$, mens en tredjedel af alle bilture er på under $5 \mathrm{~km}$ (DTU Center for Transport Analytics 2013). Danskernes smertegrænse for, hvor langt de cykler, ligger for størstedelen på 5-6 km på almindelige cykler (DTU Center for Transport Analytics 2017), men der ligger formentlig et potentiale i at overflytte pendlere fra biler til elcykler (med en topfart på $25 \mathrm{~km} / \mathrm{t}$.) og speed pedelecs (elcykler med en topfart på $45 \mathrm{~km} / \mathrm{t}$.). Elcykler og speed pedelecs indgår dog ikke i den nuværende trafikmodellering, hvilket understreger behovet for ny tidssvarende modellering, som kan understøtte udbygningen af grønnere mobilitet. Den nuværende models fokus på rejsetid resulterer altså i, at andre relevante transportfænomener såsom utryghed og trængsel på cykelstien, elcykler, fodgængere, luftforurening, støj eller $\mathrm{CO}_{2}$-udledning bliver underbelyst i den samfundsøkonomiske analyse, fordi målet for den samfundsøkonomiske analyse er at vinde rejsetid for bilister og kollektiv trafik, forklarer Kjems. Logikken i modellen fører til, at man i princippet burde bygge motorveje i byen, som det også er sket $\mathrm{i}$ andre byer, herunder Stockholm. I forbindelse med beslutningsgrundlag for nye infrastrukturscenarier er den nuværende trafikmodel således historisk set blevet brugt som styringsredskab for byens udvikling, hvor den i lyset af Scott (1998) har produceret et „transportsyn“ hos embedsfolk og lokalpolitikere i Københavns Kommune, som primært kalder på forbedringer i rejsetiden til bilister eller kollektiv trafik. Denne logik er meget svær at arbejde med, når man gerne vil fremme grøn mobilitet, understreger Kjems. 


\section{Samfundsøkonomiske fordele ved cyklisme}

Indtil sommeren 2018 har OTM som nævnt tidligere modelleret cyklisme på et lavere niveau end kollektiv trafik og bilisme. Men efter sommeren 2018 har kommunen i kraft af en ny opdatering af den nuværende transportmodel kunnet beregne sig frem til cost-benefit-fordele og -ulemper af forskellige cykelinfrastrukturscenarier. Opdateringen af den nuværende OTM blev en realitet, efter at Vuk på eget initiativ fik indsamlet midler nok til, at han kunne opgradere modelleringen af cyklisme i modellen. Cykelopdateringen ændrer dermed beslutningsprocessen for udbygningen af cykelstier markant, idet modelleringen nu kan indgå i den samfundsøkonomiske analyse. Når der skal investeres i store infrastrukturprojekter, er samfundsøkonomiske cost-benefit-analyser som nævnt påkrævet (Krawack 2015). I lyset af Wendy Espeland og Mitchell Stevens Foucault-inspirerede idéer om kvantificering (1998) er cyklisme i kraft af modelopdateringen blevet ,virkelig" blandt embedsfolk og lokalpolitikere, fordi der nu er knyttet konkrete tal til fænomenet. Disse datarepræsentationer af cyklisme kan nu bruges til at gøre trafikfænomenet synligt (Scott 1998) samt til at fortælle historier om cyklisme med stor bredde og tyngde (Stevens \& Espeland 2010:426). Et eksempel på sådan en fortælling kan læses i rapporten „Samfundsøkonomisk analyse af supercykelstierne" (2018) udarbejdet af konsulentbureauet Incentive for Sekretariatet for Supercykelstier. Her fremgår det, at ,en samlet investering i visionsplanen for supercykelstier vil give et årligt samfundsøkonomisk afkast på $11 \%$, svarende til 5,7 mia. kr." (Incentive 2018). I samme rapport opsummeres det, at en fuld finansiering af supercykelstierne medfører en reduktion i $\mathrm{CO}_{2}$-udledning på 1.500 tons, en reduktion af NOx-udledning (kvælstofilter) på $2.500 \mathrm{~kg}$, mens antallet af sygedage forventes at falde med 40.000 pr. år (ibid.). Supercykelstiernes samfundsøkonomiske afkast er med andre ord blevet gjort sammenligneligt med bilisme og kollektiv trafik (Espeland \& Stevens 1998:314). I rapporten står der desuden, at det samfundsøkonomiske afkast for supercykelstier er væsentligt højere, end afkastet er for nye motorveje. Planlagte motorveje som for eksempel Københavns nye havnetunnel eller udvidelsen af Frederikssundmotorvejen har blot et samfundsøkonomisk afkast på henholdsvis 4 og 5,6 procent (Hjuler 2019: 26). Finansministeriet har opgjort, at infrastrukturinvesteringer er samfundsøkonomisk rentable, hvis det årlige afkast er højere end 4 procent for investeringer, der strækker sig op til 35 år (Finansministeriet 2018b).

I ovenstående har vi set, hvordan den snævre trafikmodel indtil sommeren 2018 har favoriseret modelleringen af bilisme og kollektiv trafik. Modellen er en central faktor i forbindelse med samfundsøkonomiske analyser, idet dens fokus på trængsel favoriserer bilister og foranlediger lokalpolitikere til at forbedre bilisters køreforhold. Den nye cykelopdatering betyder endvidere i lyset af Espeland og 
Stevens (1998:314), at samfundsøkonomiske beregninger af supercykelstierne nu er blevet gjort kommensurable med bilisme og kollektiv trafik. Dette muliggør en sammenligning af potentielle infrastrukturscenarier, der demonstrerer, at infrastrukturinvesteringer for cyklisme fremstår mere fordelagtige i et samfundsøkonomisk perspektiv sammenlignet med bilisme. Cyklisme er med andre ord blevet gjort synlig som teknoøkonomisk forvaltningsobjekt, og er dermed som trafikfænomen blevet langt mere modtageligt over for kommunale interventioner på lige fod med kollektiv trafik og bilisme (Scott 1998:22). I næste afsnit diskuteres motivationen for at bygge den nye trafikmodel, samt hvilke nye parametre der indgår i den.

\section{Finmasket trafikmodellering og højere brugervenlighed}

Den nye udvidede transportmodel for hovedstaden har en pris på 15 millioner kroner. Den bliver udviklet af det rådgivende ingeniørfirma MOE Tetraplan med en række underleverandører, herunder blandt andet Center for Transport Analytics (Danmarks Tekniske Universitet) og Goran Vuk. Den nye, udvidede model bygger videre på den nuværende models seneste cykeltilføjelse, og den dækker det samme geografiske område. Men den bliver udviklet på grundlag af ny, tidssvarende software. Kjems forklarer, at en af de væsentligste grunde til at lave den nye model er, at den nuværende model er relativt grovmasket, selv om den er blevet forbedret i sin seneste version med cykelopdateringen. Således opdeler den nuværende model hovedstadsområdet i 4.000 zoner, mens den nye model kommer til at arbejde med 10.000 zoner. Problemet med relativt store zoner er ifølge Kjems, at mange ture dermed befinder sig inden for samme zone, hvilket betyder, at turene ikke tæller med i trafikmodellen. En tur skal således gå fra en zone til en anden, før den gør sig gældende i trafikmodellen. Detaljegraden er altså betydeligt højere i den kommende model, og flere korte ture bliver registreret som følge af den mere finmaskede zoneinddeling. I henhold til Geoffrey Bowker og Susan Stars idé om, at klassificeringer kan forstås som rumlige segmenteringer af verden (Bowker \& Star 2000:10), kan man sige, at de nye zoner åbner op for nye former for bureaukratisk arbejde. Den nuværende, snævre model er nemlig typisk blevet brugt til beregning af store infrastrukturprojekter såsom metro eller motorvej, hvorimod den nye model også skal kunne bruges til at sige noget meningsfuldt om enkelte, mindre veje i byen. Modellen bliver opbygget efter brugercasescenarier, som afspejler brugssituationer for forskellige relevante aktører, herunder trafikingeniører, strategiske planlæggere eller beslutningstagere. Når der for eksempel skal afholdes events i Københavns gader, er tanken, at den nye model skal bruges til at vurdere, hvordan offentlige begivenheder influerer på trafikken. Er det for eksempel smartest at lade Copenhagen Pride passere gen- 
nem Vesterbrogade frem for Istedgade i forhold til byens trafik? I hvilken gade bliver den øvrige trafik mindst generet? På samme måde skal modellen kunne fortælle brugeren noget om trafikale ændringer, hvis København skal afholde et Formel 1-løb, Langebro skal repareres, der er oversvømmelse på Lyngbyvej eller demonstration på Rådhuspladsen. Ved den slags begivenheder skal modellen producere et output angående nye rejsetider for bilister, kollektiv trafik osv. Modellen skal også være i stand til at beregne effekten af nye parkeringspolitikker, delebiler samt eventuelt kommende førerløse køretøjer, som fremtiden måtte byde os. I modsætning til den nuværende model medregnes kapacitetsbegrænsninger i kollektiv trafik også. Manglende kapacitet i kollektive transportformer betyder, at rejsende vælger andre transportformer, hvilket er centralt at få med i modelleringen. I modsætning til den nuværende model kan den nye model ligeledes beregne kombinationsrejser, hvilket er afgørende for transportsystemer, hvor forskellige transportformer kombineres. Det kunne for eksempel være cykelmedtagning i tog eller kombineret biltur med cykel. Den mere finmaskede model skal i forlængelse heraf også kunne benyttes til beregning af effekterne af nye eller forbedrede cykelparkeringsanlæg ved togstationer. Dette er eksempler på, hvordan den nye, bredere model løfter sløret (Heidegger i Verbeek 2011: 67-68) for nye trafikfænomener og gør disse bedre modtagelige for kommunal intervention (Scott 1998:22).

\section{Konklusion: transportmodellers rolle i forbindelse med omstilling til grøn mobilitet}

Helt grundlæggende er det vigtigt at understrege, at trafikmodeller - i lighed med mange andre ting - er produkter af den tid, de bliver udviklet i. Transportmodellering ændrer sig med andre ord løbende, i takt med at samfundet ændrer sig. Der vil derfor altid være behov for, at en trafikmodel udvikler sig, i takt med at byens rum redesignes, og nye mobilitetsmodi kommer frem. I denne artikel har jeg slået ned på nogle af de væsentlige forbedringer, som opdateringer af trafikmodellering har medført og medfører i henhold til beregning af blandt andet cyklisme, fodgængere, højere brugervenlighed, kombinationsrejser og højere detaljegrad. Artiklen demonstrerer, hvordan trafikmodeller forstået som teknologi producerer særlige transportsyn blandt embedsfolk og lokalpolitikere, i og med at bestemte trafikfænomener fremhæves på bekostning af andre. Den nuværende, snævre model har således været med til at forstærke og fastholde et dominerende bilregime i København og omegn i løbet af sin levetid. Dette modelleringsbias i forhold til bilisme er der først blevet gjort op med i løbet af de seneste år, hvilket har betydet, at cyklisme først i sommeren 2018 model- 
leres på samme niveau som bilisme og kollektiv trafik, mens modelleringen af fodgængere stadig halter bagefter.

Trafikmodeller er ikke sat i verden for at skulle bestemme, hvilken by vi skal leve i, men analysen demonstrerer, at de i høj grad netop medvirker til at bestemme og udforme de københavnske gader, idet modelleringen afgør, hvilke trafikfænomener der kan ses blandt beslutningstagere. Når trafikmodelleringen således fremhæver (Verbeek 2011:8-9) og synliggør (Scott 1998:22) rejsetid, bliver rejsetid det trafikfænomen, som trafikplanlæggere, embedsmænd eller lokalpolitikere forholder sig til og prioriterer at forbedre. I lyset af Københavns mål om at blive en $\mathrm{CO}_{2}$-neutral hovedstad i 2025 fremstår den nuværende trafikmodel som et forældet beslutningsstøtteværktøj, der i ringe grad understøtter Københavns klimamålsætning. Historisk set har trafikmodellen som beslutningsstøtteredskab snarere modarbejdet Københavns $\mathrm{CO}_{2}$-mål på grund af modelleringens bias til fordel for bilisme. I og med at $\mathrm{CO}_{2}$-udledning fra trafik hverken fremhæves som et centralt element $i$ den nuværende eller den kommende trafikmodel, fremstår ingen af trafikmodellerne i deres nuværende version som værktøjer, der i særlig grad understøtter målet om $\mathrm{CO}_{2}$-neutralitet i 2025. Sammenlignet med den nuværende model fremstår den kommende udvidede model dog som en mindre bilcentreret og mere realistisk opgradering af dette helt centrale urbane styringsredskab, der i højere grad vil kunne understøtte udbygningen af grøn mobilitet. Men modellens manglende fokus på sammenhængen mellem infrastrukturinvesteringer, luftforurening og $\mathrm{CO}_{2}$-udledning understreger, at dette centrale styringsredskab bør justeres yderligere i henhold til kommunens klimamål.

\section{Tak}

Tak til de medvirkende i dette forskningsprojekt: Marie Kåstrup, programleder for cyklisme i Københavns Kommune, Sidsel Hjuler, leder af Supercykelsti Sekretariatet, Klaus Bondam, formand for Cyklistforbundet, samt Goran Vuk, selvstændig, og Sidsel Kjems, chefkonsulent i Københavns Kommune. Særlig tak til Goran Vuk og Sidsel Kjems for at læse og kommentere et udkast af artiklen samt svare på opfølgende spørgsmål.

\section{Litteratur}

Andersen, Jeppe

2013 The Shaping of Transport Model-Based Knowledge Production. Ph.d.-afhandling. Aalborg University. http://vbn.aau.dk/files/157595403/The_Shaping_of_

Transport_Model_Based_Knowledge_Production.pdf. 
Apthorpe, Raymond

1997 Writing Development Policy and Policy Analysis Plain and Clear. On Language,

Genre and Power. In: C. Shore \& S. Wright (eds): Anthropology of Policy.

Critical Perspectives on Governance and Power. Pp. 34-46. London \& New York:

Routledge.

Astrup, Søren

2017 Hårde valg venter. Hvad skal København gøre ved cykeltrafikken, når byen får 100.000 flere indbyggere? Politiken 23.2. https://politiken.dk/indland/kobenhavn/ art5843060/Hvad-skal-K\%C3\%B8benhavn-g\%C3\%B8re-ved-cykeltrafikken$\mathrm{n} \% \mathrm{C} 3 \% \mathrm{~A} 5 \mathrm{r}-$ byen-f\%C $3 \% \mathrm{~A} 5 \mathrm{r}-100.000$-flere-indbyggere.

Bowker, Geoffrey \& Susan Leigh Star

$2000 \quad$ Sorting Things Out. Classification and Its Consequences. Cambridge, MA, \& London, England: The MIT Press.

Dreze, Jean \& Nicholas Stern

1987 Chapter 14: The Theory of Cost-Benefit Analysis. In: A.J. Auerbach \& M.

Feldstein (eds): Handbook of Public Economics, vol. II. Pp. 909-89. Amsterdam:

North Holland.

DTU Center for Transport Analytics

2013 Faktaark om biltransport i Danmark. https://www.cta.man.dtu.dk/transportvaneun dersoegelsen/udgivelser/faktaark/faktaark-om-biltransport-i-danmark-2013. Læst 17.1.2019.

2017 Faktaark om cykeltrafik i Danmark. https://www.cta.man.dtu.dk/transportvaneun dersoegelsen/udgivelser/faktaark/faktaark-om-cykeltrafik-i-danmark-2014. Læst 17.1.2019.

2019 Modelbibliotek. TERESA. https://www.cta.man.dtu.dk/Modelbibliotek/TERESA Læst 17.1.2019.

Espeland, Wendy Nelson \& Mitchell L. Stevens

1998 Commensuration as a Social process. Annual Review of Sociology 24:313-43. DOI: https://doi.org/10.1146/annurev.soc.24.1.313.

2010 A Sociology of Quantification. European Journal of Sociology 49(3):401-36. DOI: https://doi.org/10.1017/S0003975609000150.

Finansministeriet

2018a Regneprincipper og modelanvendelse. Dynamiske effekter af offentligt forbrug og offentlige investeringer. https://www.fm.dk/ /media/files/oekonomi-og-tal/ fm-regnemetoder/regneprincipper-og-modelanvendelse--dynamiske-effekter-afoffentligt-forbrug-og-offentlige-investeringer.ashx?la=da. Læst 17.1.2019.

2018 b Den samfundsøkonomiske diskonteringsrente. https://www.fm.dk/oekonomi-ogtal/finansministeriets-regnemetoder. Læst 17.1.2019.

Graeber, David

2001 Toward an Anthropological Theory of Value. The False Coin of Our Own Dreams. New York: Palgrave.

Hansen, Helle Ploug

1997 Patients' Bodies and Discourses of Power. In: C. Shore \& S. Wright (eds):

Anthropology of Policy. Critical Perspectives on Governance and Power. Pp. 68-

83. London \& New York: Routledge.

Hjuler, Sidsel

2019 Derfor er cyklen masterplanens lavpraktiske nøglekomponent. Trafik og Veje, januar:26-28. 
Ho, Karen

2009 Liquidated. An Ethnography of Wall Street. Durham \& London: Duke University Press.

Incentive

2018 Samfundsøkonomisk analyse af supercykelstierne. http://www.incentive.dk/ wp-content/uploads/2018/06/Incentive_Samfundsøkonomisk-analyse-afsupercykelstier.pdf. Læst 17.1.2019.

Jensen, Jens Stissing, Matthew Cashmore \& Morten Elle

2017 Reinventing the Bicycle. How Calculative Practices Shape Urban Environmental

Governance. Environmental Politics 26(3):459-79. https://doi.org/10.1080/

09644016.2017.1311089.

Kaposy, Chris

2015 Postphenomenology of the Robot Medical Student. In: R. Rosenberger \& P.-

P. Verbeek (eds): Postphenomenological Investigations. Essays on Human

Technology Relations. Pp. 191-203. London: Lexington Books.

Kjems, Sidsel, Henrik Paag \& Christian Hansen

2018 Københavns Kommune udvikler ny trafikmodel for hovedstadsområdet. Trafik og Veje, november:18-19.

Krawack, Susanne

2015 Samfundsøkonomiske vurderinger i klimapolitikken. Concito. https://concito.dk/

files/dokumenter/artikler/samfundsoekonomiske_vurderinger_260215.pdf. Læst

17.1.2019.

Københavns Kommune

2019a 62 procent af københavnerne cykler til arbejde og uddannelse. https://www.kk.dk/ indhold/62-af-koebenhavnerne-cykler-til-arbejde-og-uddannelse. Læst 17.1.2019.

2019 b $\quad \mathrm{CO}_{2}$-regnskab for 2018. Kortlægning for kommunen som samfund. https://

kk.sites.itera.dk/apps/kk_pub2/index.asp?mode=detalje\&id=1982. Læst 17.1.2019.

Liebermann, Edward B.

2015 Brief History of Traffic Simulation. In: L. Camarda (ed.): Traffic and

Transportation Simulation. Looking Back and Looking Ahead. Celebrating 50

Years of Traffic Flow Theory, a Workshop. Transportation Research Circular No.

E-C195. Pp. 17-29. http://onlinepubs.trb.org/onlinepubs/circulars/ec195.pdf.

Maurer, Bill

2006 The Anthropology of Money. Annual Review of Anthropology 35:15-36. DOI:

https://doi.org/10.1146/annurev.anthro.35.081705.123127.

McGhie, Steffen

$2018 \quad 450.000$ nye biler på 10 år. Trængslen vokser med uformindsket styrke. Ingeniøren

9.7. https://ing.dk/artikel/450000-nye-biler-paa-10-aar-traengslen-vokser-med-

uformindsket-styrke-213290.

Nader, Laura

1972 Up the Anthropologist. Perspectives Gained from Studying Up. In: D. Hymes

(ed.): Reinventing Anthropology. Pp. 284-311. New York: Pantheon Books.

Riis, Søren

2015 A Century on Speed. Reflections on Movement and Mobility in the Twentieth

Century. In: R. Rosenberger \& P.-P. Verbeek (eds): Postphenomenological

Investigations. Essays on Human Technology Relations. Pp. 159-75. London:

Lexington Books. 
Scott, James

1998

Seeing Like a State. New York: Yale University Press.

Shore, Cris \& Susan Wright (eds)

1997 Anthropology of Policy. Critical Perspectives on Governance and Power. London \& New York: Routledge.

Van Den Eede, Yoni

2015 Tracing the Tracker. A Postphenomenological Inquiry into Self Tracking Technologies. In: R. Rosenberger \& P-P. Verbeek (eds): Postphenomenological Investigations. Essays on Human Technology Relations. Pp. 143-59. London: Lexington Books.

Verbeek, Peter-Paul

2011 Moralizing Technology. Understanding and Designing the Morality of Things. London: University of Chicago Press. 